\title{
Structure formation and properties of thermochemically modified silicate-sodium compositions
}

\author{
Yuri Ivaschenko, Maria Kochergina* and Irina Pavlova \\ Yuri Gagarin State Technical University of Saratov, Department "Building Materials and \\ Technologies", Polytechnic St., 77, Saratov, Russia
}

\begin{abstract}
Modern methods allow to improve the functional properties of silicate-sodium compositions. Increased water resistance primarily will allow their use in construction. The article presents the results of the study of modified silicate-sodium compositions by X-ray phase analysis, differential thermal analysis, thermo-gravimetric analysis. An organic zinccontaining compound, zinc acetate dihydrate, which is introduced into the binder in the form of a concentrated aqueous fluid, was used as a modifier. Using X-ray analysis, it was shown that in the hardening system "silicatesodium binder - an aqueous fluid of zinc acetate" in the temperature range $110-450{ }^{\circ} \mathrm{C}$ various forms of hydroxides, silicates and zinc silicates are formed. In addition, at $\mathrm{T}=450^{\circ} \mathrm{C}$, only "traces" of $\mathrm{ZnO}$ were detected, and the crystalline phase of the hardly soluble zinc metasilicate $\mathrm{ZnSiO}_{3}$ prevailed. The results of the study of modified samples by thermal analysis indicate the processes of thermal decomposition of the modifying additive in the binder system and indicate the possible formation of a new crystalline phase $\left(\mathrm{ZnSiO}_{3}\right)$ at a temperature of $440-450{ }^{\circ} \mathrm{C}$. It was revealed that temperature treatment of modified samples in the range of $440-450{ }^{\circ} \mathrm{C}$ leads to a more significant increase in water resistance (by 25-28\%) than during low-temperature curing (by 20-23\%).
\end{abstract}

\section{Introduction}

The priority directions of development of the building materials industry are to ensure the quality and competitiveness of products, reduce the energy intensity of the production process, use local raw materials, and increase their production.

Prospects of using silicate-sodium binder (SSB) to obtain a wide range of building materials with desired properties are due to: the presence of a complex of binding properties, adhesive and cohesive components; high chemical activity; ability to swell when exposed to elevated temperatures; manufacturability and availability of raw materials for their production; a complex of properties in products - resistance to high temperatures, corrosive media (diluted and concentrated acids) [1-9].

Analysis of the scientific and technical literature has shown that increasing the water resistance of silicate-sodium materials is achieved by modifying the SSB with polyvalent

\footnotetext{
* Corresponding author: m-kochergina@list.ru
} 
metal oxides and hydroxides [8, 10-14]. Of interest is the variant of the process in situ, when the formation of $\mathrm{MeO}$ and $\mathrm{Me}(\mathrm{OH})_{2}$ would be carried out directly in the sodium silicate matrix. Attention is drawn to the methods used in the directional synthesis of fine particles of metals and their compounds in organic polymer matrices. Such methods are based on the use as precursors of metal salts (mainly nitrates, sulfates, oxalates and acetates), which are capable of alkaline hydrolysis to form $\mathrm{Me}(\mathrm{OH})_{2}$, and during thermolysis decompose to the corresponding $\mathrm{MeO}$ [15-17].

Based on the above, the WORKING HYPOTHESIS has been put forward, which consists in the possible formation of sparingly soluble compounds through the alkaline hydrolysis stage, as well as the thermolysis of polyvalent metal salts directly in the binder volume at temperatures of $400-900{ }^{\circ} \mathrm{C}$, thereby enhancing the water resistance of silicate sodium materials.

\section{Materials and Methods}

The main objects of the study were modified silicate-sodium compositions (SSC) on the basis of marketable liquid sodium glass, corresponding to GOST 13078-81 ( $\rho=1480 \mathrm{~kg} / \mathrm{m}^{3}$; silicate module $\mathrm{M}=2.7$ ). Organic zinc-containing compound - zinc acetate dihydrate (GOST 5823-78) was used as a modifier. Sodium silicofluoride was used as a hardener in the compositions (TU 6-09-05807960-114-94). Quartz sand (0.65-2.5 mm), silica quartz sand $\left(\mathrm{S}=250-500 \mathrm{~m}^{2} / \mathrm{kg}\right)$, and fine-milled flask with $\mathrm{S}=300-350 \mathrm{~m}^{2} / \mathrm{kg}$ were used as fillers.

The patterns of structure formation of SSC were studied using a complex of modern physicochemical methods of analysis. X-ray diffraction (XRD) phase analysis (XRD) was performed on a DRON-3 and DRON-4 diffractometer using an X-ray tube with a copper anode $(\mathrm{Cu}-\mathrm{K}$ radiation). The diffractograms were analyzed using the PCPDFWIN, $\mathrm{V}$ database. 2.02, 1999, The Joint Committeed on Powder Diffraction Standards (JCPDS). XRD) phase analysis was also conducted on an ARL X'TRA diffractometer on the basis of the Scientific and Educational Center for Nanotechnologies and Nanomaterials of the Yuri Gagarin State Technical University (SSTU). Differential thermal analysis (DTA) and thermo-gravimetric analysis (TGA) were carried out with the help of a hardware-software complex (developed by IP TETRAN LLC). Studies were performed on a Q-1500D derivatograph (IOM, Budapest).

The water resistance of silicate-sodium composites was estimated by the value of the softening coefficient $\left(\mathrm{K}_{\mathrm{r}}\right)$, which is equal to the ratio of strength indicators $\mathrm{R}_{\text {szh }}$ of samples in the water-saturated and initial state. The compressive strength of the original and watersaturated samples was determined according to the requirements of GOST 310.4-81, GOST 10180-2012, GOST 25881-83 using a test hydraulic test model PGM-100 MG4 and a press model PM-20-MG4. In the case of low-temperature curing by SSC, the samples were made in the form of standard beams of $40 \times 40 \times 160 \mathrm{~mm}$ in size, the saturation of which was carried out for two days in tap water. In the case of using high-temperature heat processing of SSC, the samples were made in the form of prisms of size $20 \times 20 \times 30 \mathrm{~mm}$, the water saturation of which was carried out during the day night in tap water.

\section{Results and Discussion}

It was previously established that the modifier, zinc acetate (ZA), is most efficiently introduced into the binder in the form of a saturated aqueous solution with a concentration of $20-28 \%$. An increase in the water resistance of composites by $20-28 \%$ is achieved by 
modifying the silicate-sodium binder (SSB) with zinc acetate as fluid within $2.1-3.6 \%$ in terms of the basic substance [18-19].

During the interaction of an aqueous alkaline solution of sodium silicate and an aqueous solution of the ZA in the SSB system, a white precipitate is observed in the form of bulky fibrous (loose) clots. The study of the modified SSB at the stage of low-temperature curing $\left(\mathrm{T}=110-180^{\circ} \mathrm{C}\right)$ using the XRF method showed that the system most likely to produce zinc hydrosilicate $\mathrm{Zn}_{2} \mathrm{SiO}_{4} \mathrm{H}_{2} \mathrm{O}$ and $\gamma-\mathrm{Zn}(\mathrm{OH})_{2}$ hydroxide, possibly the presence of $\delta-\mathrm{Zn}(\mathrm{OH})_{2} \cdot 0.5 \mathrm{H}_{2} \mathrm{O}$ and zinc orthosilicate $\beta-\mathrm{Zn}_{2} \mathrm{SiO}_{4}[20]$.

The study of the interaction of the binder with the modifier under the conditions of exposure to temperatures from $200^{\circ} \mathrm{C}$ to $450^{\circ} \mathrm{C}$ allowed us to establish the following.

Not fully hydrolyzed zinc acetate and zinc hydroxide, the formation of which is carried out in the initial stages, undergo thermolysis to zinc oxide, as evidenced by X-ray diffraction data of samples modified with $24 \%$ aqueous solution of $\mathrm{ZA}$ in the range of $10-15 \%$ by weight of SSB (Table 1). All samples also recorded a large amount of amorphous phase. However, the appearance of characteristic $\mathrm{X}$-ray lines of the $\mathrm{ZnO}$ phase is noted on the diffraction pattern of the samples cured at $\mathrm{T}=250^{\circ} \mathrm{C}$, which may result from the decomposition of the corresponding hydroxides. On this X-ray diffraction pattern, traces of $\gamma-\mathrm{Zn}(\mathrm{OH})_{2}$ reflections were found.

On the X-ray diffraction pattern of a sample containing a modifying solution in an amount of $15 \%$ by weight SSB and dehydrated at $\mathrm{T}=250{ }^{\circ} \mathrm{C}$, there are reflexes characteristic of anhydrous zinc acetate $\mathrm{Zn}\left(\mathrm{C}_{2} \mathrm{H}_{3} \mathrm{O}_{2}\right)_{2}$, at $\mathrm{T}=400{ }^{\circ} \mathrm{C}$, only "traces" of $\mathrm{Zn}$ reflexes $\left(\mathrm{C}_{2} \mathrm{H}_{3} \mathrm{O}_{2}\right)_{2}$, which may indicate the processes of its decomposition in this temperature range. It is known that decomposition of zinc acetate dihydrate when heated occurs stepwise according to the following scheme:

$$
\begin{aligned}
& \left(109^{\circ} \mathrm{C}\right) \quad\left(235^{\circ} \mathrm{C}\right) \quad\left(330^{\circ} \mathrm{C}\right) \\
& \mathrm{Zn}\left(\mathrm{CH}_{3} \mathrm{COO}\right)_{2} \cdot 2 \mathrm{H}_{2} \mathrm{O} \rightarrow \mathrm{Zn}\left(\mathrm{CH}_{3} \mathrm{COO}\right)_{2}+2 \mathrm{H}_{2} \mathrm{O} \rightarrow \mathrm{Zn}\left(\mathrm{CH}_{3} \mathrm{CO}_{2}\right)_{2} \text { melt } \rightarrow \\
& \left(400^{\circ} \mathrm{C}\right) \\
& \rightarrow \mathrm{ZnO}+\mathrm{CH}_{3} \mathrm{COCH}_{3}+\mathrm{CO}_{2} \uparrow-\mathrm{ZnO}
\end{aligned}
$$

In all the modified samples, dehydrated at $\mathrm{T}=450^{\circ} \mathrm{C}$, only "traces" of $\mathrm{ZnO}$ were found, and a dominant crystalline phase appeared $-\mathrm{ZnSiO}_{3}$ zinc metasilicate; $\mathrm{ZnNa}_{2} \mathrm{SiO}_{4} \cdot \mathrm{H}_{2} \mathrm{O}$ may be present. Due to the dehydration of $\mathrm{CH}_{3} \mathrm{COONa} \cdot 3 \mathrm{H}_{2} \mathrm{O}$, the anhydrous sodium acetate $\mathrm{CH}_{3} \mathrm{COONa}$ phase appears on the $\mathrm{X}$-ray diffraction pattern of the samples. In accordance with the decomposition scheme of sodium acetate trihydrate $\left(\mathrm{CH}_{3} \mathrm{COONa} \cdot 3 \mathrm{H}_{2} \mathrm{O}\right)$ when heated, the temperature range of $400-450{ }^{\circ} \mathrm{C}$ corresponds to the beginning of the decomposition of anhydrous salt to sodium carbonate. On the X-ray diffraction patterns, no obvious reflections of $\mathrm{Na}_{2} \mathrm{CO}_{3}$ were detected, however, a decrease in the intensity of the lines characteristic of anhydrous salt, $\mathrm{CH}_{3} \mathrm{COONa}$, is observed. It should be noted that in all X-ray diffraction patterns no crystalline phases of sodium silicates were detected.

The mechanism of formation of sparingly soluble zinc-containing complexes is quite complicated, $\mathrm{ZnNa} 2 \mathrm{SiO} 4 \cdot \mathrm{H} 2 \mathrm{O}$ can be formed according to the scheme:

$$
\left[\mathrm{Zn}(\mathrm{OH})_{4}\right]_{2-}+\mathrm{Na}_{2} \mathrm{SiO}_{3} \mathrm{mH}_{2} \mathrm{O} \rightarrow \mathrm{ZnNa}_{2} \mathrm{SiO}_{4} \mathrm{mH}_{2} \mathrm{O}
$$

The appearance of the dominant crystalline phase of $\mathrm{ZnSiO}_{3}$ may be the result of reactions taking place both at $\mathrm{T}=450^{\circ} \mathrm{C}$ and at earlier stages.

In order to obtain additional information, thermal analysis and microscopic studies of the SSC were performed. 
Table 1. High-quality XRD samples subjected to heat processing the temperature of $110-450{ }^{\circ} \mathrm{C}$.

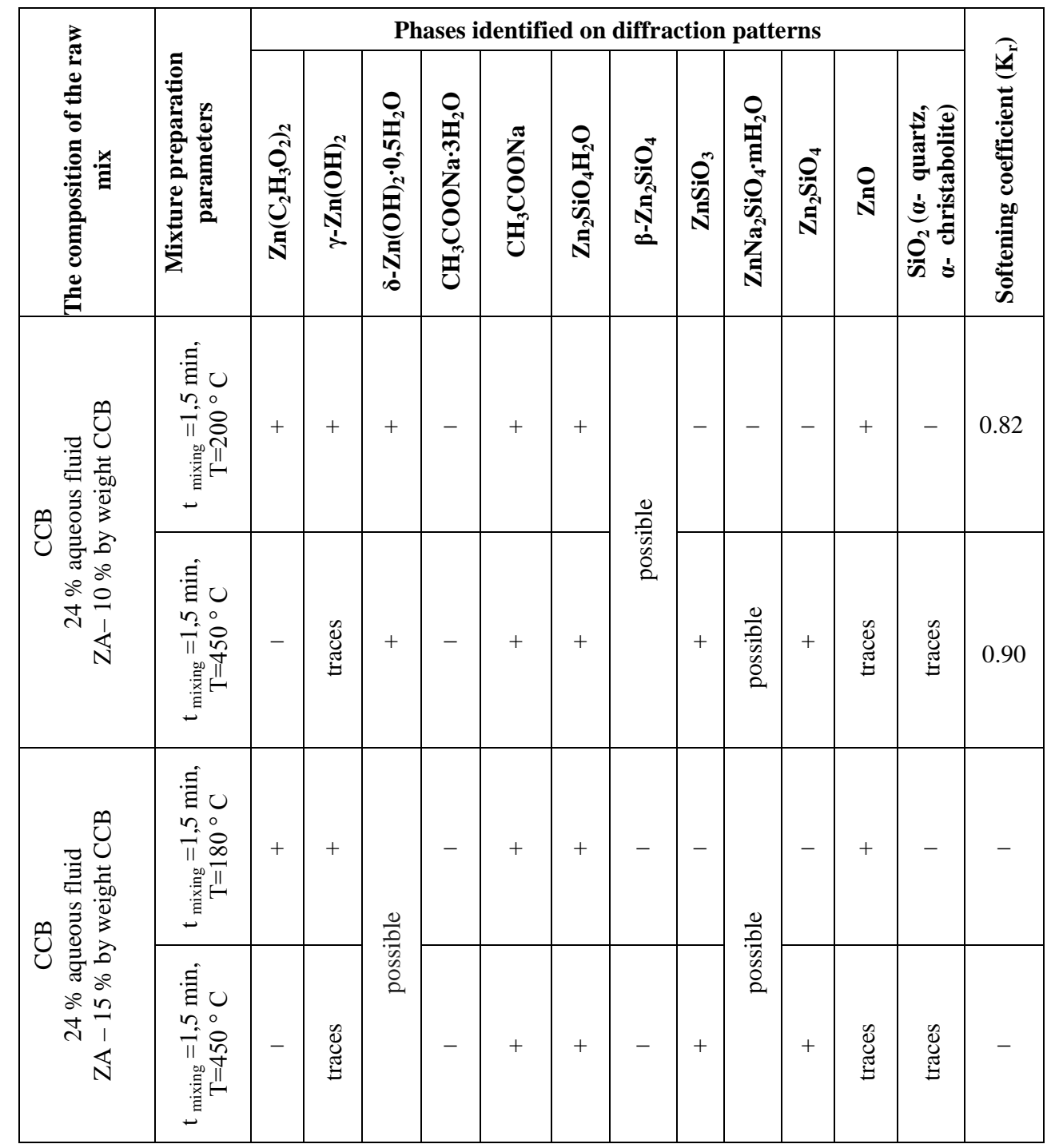

According to known data, decomposition of ZA dihydrate is a multistage process. On the $\mathrm{Zn}\left(\mathrm{C}_{2} \mathrm{H}_{3} \mathrm{O}_{2}\right)_{2} * 2 \mathrm{H}_{2} \mathrm{O}$ thermograms, the following effects are noted: endothermic effect at $\mathrm{T}=120^{\circ} \mathrm{C}$, which is associated with the removal of crystal hydrate water to form anhydrous salt; endothermic effect $\mathrm{T}=250^{\circ} \mathrm{C}$, which is explained by melting tetraoxoacetate according to scheme 3.5; exothermic effect at $\mathrm{T}=370^{\circ} \mathrm{C}$, which is associated with the decomposition of zinc tetraoxoacetate to $\mathrm{ZnO}$; the exothermic effect at $\mathrm{T}=400^{\circ} \mathrm{C}$ is associated with the burning of acetone formed during the decomposition of the compound.

Figure 1a presents TGA and DTA data for a composition based on SNA with hardener $\mathrm{SF}$ (sodium fluoride). At the initial stage, in the temperature range from $100^{\circ} \mathrm{C}$ to $220^{\circ} \mathrm{C}$, the system under investigation is dehydrated, which is accompanied by maximum mass losses and, in turn, is confirmed by a step on the TG curve and a strong endothermic peak. 


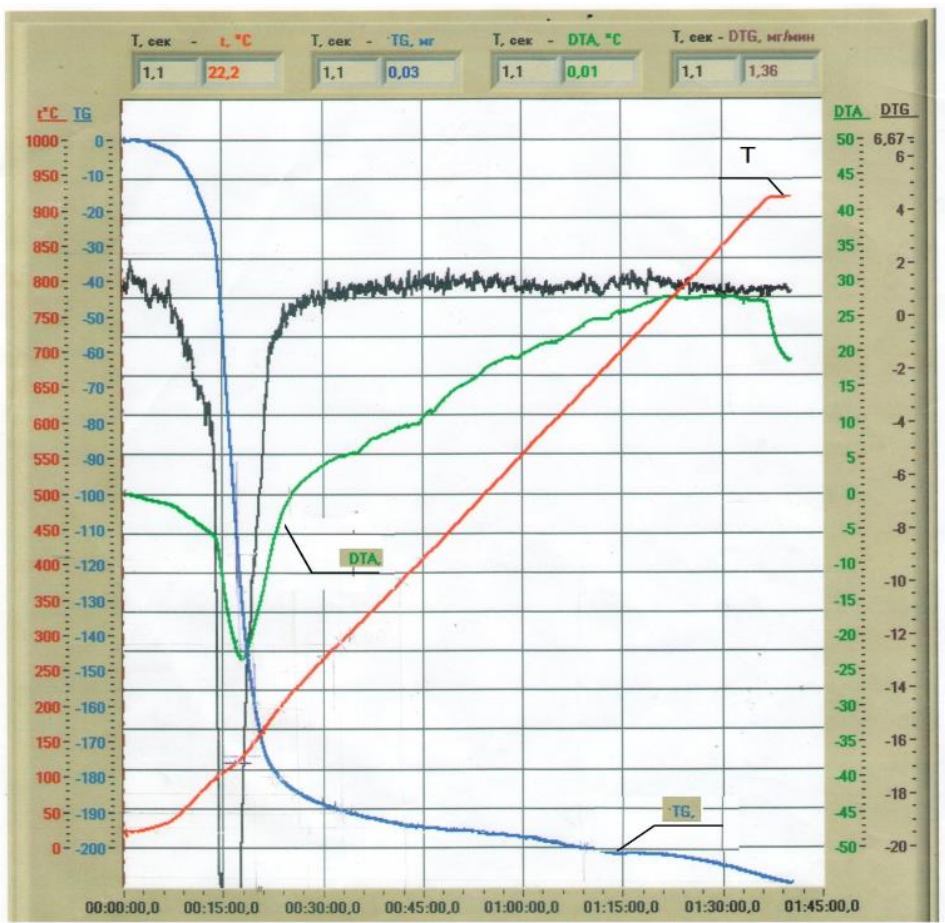

a)

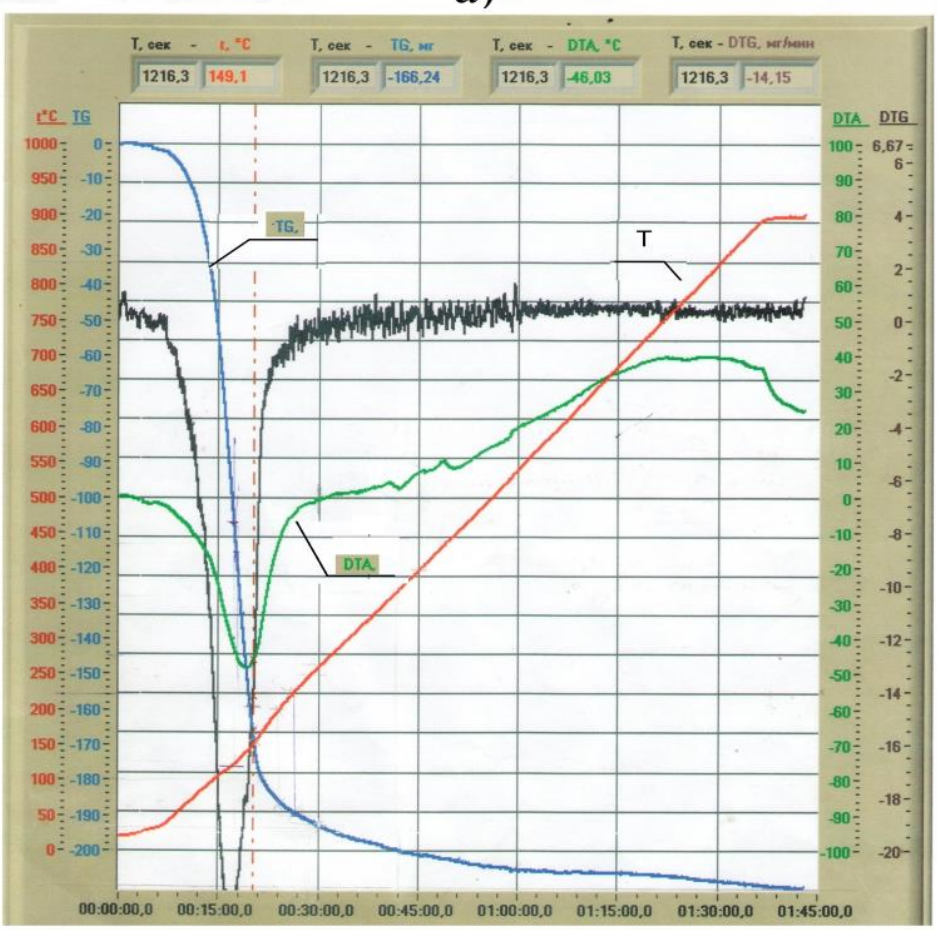

b)

Fig. 1. Data of thermal analysis of the composition: a) SSB - SF; b) SSB- aqueous fluid ZA - SF. 
Figure $1 \mathrm{~b}$ presents the data of TGA and DTA for the SSB system - an aqueous solution of AC - SF. The DTA curve of the SNS-water system AC - SF solution also has a strong endothermic effect, which corresponds to the maximum mass loss in the TG curve, which is due to the dehydration of the system. The appearance of additional peaks on the DTA curve in the temperature range from $340^{\circ} \mathrm{C}$ to $440^{\circ} \mathrm{C}$ is noted. According to X-ray powder diffraction data, the system does not contain hydrolyzed zinc acetate dihydrate. According to the DTA zinc acetate dihydrate in the temperature range from $250{ }^{\circ} \mathrm{C}$ to $400^{\circ} \mathrm{C}$, zinc tetraoxoacetate is decomposed to $\mathrm{ZnO}$.

Thus, the appearance of thermal effects on the DTA-curve of the modified zinc acetate system in the temperature range from $340^{\circ} \mathrm{C}$ to $400^{\circ} \mathrm{C}$ (Figure $1 \mathrm{~b}$ ) may indicate the passage of thermal decomposition processes of $\mathrm{Zn}\left(\mathrm{C}_{2} \mathrm{H}_{3} \mathrm{O}_{2}\right)_{2} \cdot 2 \mathrm{H}_{2} \mathrm{O}$ to $\mathrm{ZnO}$. The exothermic effect at a temperature of $440{ }^{\circ} \mathrm{C}$ may be associated with the formation of a new crystalline phase $\mathrm{ZnSiO}_{3}$, which is identified on the X-ray diffraction pattern of a similar sample subjected to heat treatment at $450^{\circ} \mathrm{C}$. It is known that the exothermic effect is fixed in a narrow temperature range with intense sharp and symmetrical peaks, indicates the "explosive" nature of the transformations and usually corresponds to the formation of a new crystalline phase. However, one should not exclude the transition from the amorphous to the crystalline state.

\section{Conclusions}

1. Theoretically justified and experimentally confirmed the possibility of using zinc acetate as a modifying agent for the SSB, contributing to the improvement of water resistance.

2. Installed structural changes in the SSB during thermochemical modification. Using X-ray phase and thermal analyzes, it was shown that non-hydrolyzed ZA and unreacted zinc hydroxides can undergo thermolysis in the temperature range of $200-450{ }^{\circ} \mathrm{C}$ to form $\mathrm{ZnO}$ and additionally participate in the synthesis of sparingly soluble complexes in a sodiumsodium system.

3. It was experimentally established that temperature processing in the range of $440-450{ }^{\circ} \mathrm{C}$ leads to a more significant increase in water resistance (by $25-28 \%$ ) than during low-temperature curing. should be centred and should be numbered with the number on the right-hand side.

\section{References}

1. V. I. Korneev, V. V. Danilov, ZHidkoe i rastvorimoe steklo, 216 (Strojizdat, SPb, 1996)

2. A. I. Kudyakov, N. A. Svergunova., M. YU. Ivanov, Zernistyj teploizolyacionnyj material na osnove modificirovannoj zhidkostekol'noj kompozicii, 204 (TGASU, Tomsk, 2009)

3. A. S. Brykov, Silikatnye rastvory i ih primenenie, 54 (SPbGTI (TU), SPb, 2009)

4. M. M. Sychev, Neorganicheskie klei, 152 (Himiya, Leningrad, 1986)

5. B. D. Toturbiev, Stroitel'nye materialy na osnove silikat-natrievyh kompozicij, 208 (Strojizdat, Moskva,1988)

6. I. V. Ryzhkov, B. C. Tolstoj, Fiziko-himicheskie osnovy formirovaniya svojstv smesej s zhidkim steklom, 140 (Vishcha shkola, Har'kov, 1975)

7. V. M. Hrulev, Polimersilikatnye kompozicii v stroitel'stve, 76 (TAU, UFA, 2002)

8. A. N. Grishina, E.V. Korolev, ZHidkostekol'nye stroitel'nye materialy special'nogo naznacheniya: monografiya, 222 (MGSU, Moskva, 2015) 
9. P. G. Kudryavcev, O. L. Figovskij, Nanomaterialy na osnove rastvorimyh silikatov, 165 (LAP Lambert Academic Publishing, 2014)

10. N. I. Malyavskij, O. V. Dushkin, N. V. Velikanova, Vestnik MGSU, 1, 167-169 (2007)

11. R. Ajler, Kolloidnaya himiya kremnezyoma i silikatov, 1127 (Mir, Moskva, 1982)

12.B. A. Rzhanicyn, Himicheskoe zakreplenie gruntov $v$ stroitel'stve, 263 ( Strojizdat, Moskava, 1986)

13. V. I. Sidorov, N. I. Malyavskij, B. V. Pokid'ko, Izvestiya vuzov. Stroitel'stvo, 8, 27-28 (2002)

14. V. I. Loganina, S. N. Kislicyna, M.A. Sadovnikova, Stroitel'nye materialy, 4, 87-89 (2014)

15. I. M. Vasserman, Himicheskoe osazhdenie iz rastvorov, 208 (Himiya, Leningrad, 1980)

16. I. V. Melihov, M.S. Merkulova, Sokristallizaciya, 297 (Himiya, Moskva, 1975)

17. B. V. Nekrasov, Osnovy obshchej himii, 688 (Himiya, Leningrad, 1973)

18. YU. G. Ivashchenko, I. L. Pavlova, M. P. Kochergina, NAU. Ezhemesyachnyj nauchnyj zhurnal, 1, 6, 116-118 (2015)

19. U. G. Ivashchenko, I. L. Pavlova, M. P. Kochergina, Patent RU 2623754 (2016, Byul. 10)

20. YU. G. Ivashchenko, I. L. Pavlova, M. P. Kochergina, Vestnik VolgGASU, 43, 62, 6676 (2016) 